\title{
Influence of aerial dispersal on persistence and spread of pesticide-resistant Metaseiulus occidentalis in California almond orchards
}

\author{
Marjorie A. Hoyl', J. J. Rob Groot ${ }^{2} \&$ Hugo E. van de Baan ${ }^{3}$ \\ ${ }^{1}$ Department of Entomological Sciences, University of California, Berkeley 94720, USA; ${ }^{2}$ Department of \\ Theoretical Production Ecology, Agricultural University, Wageningen. The Netherlands; ${ }^{3}$ Department of \\ Animal Ecology, Agricultural University, Wageningen, The Netherlands
}

Keywords: aerial dispersal, Metaseiulus occidentalis, Acarina, Phytoseiidae, Tetranychidae, spider mites, pesticide resistance, almonds, biological control, genetic improvement, carbaryl, western predatory mite, European red mite, two-spotted spider mite, Pacific mite

\begin{abstract}
Aerial dispersal of the phytoseiid Metaseiulus occidentalis (Nesbitt) was evaluated as a component in managing pesticide-resistant populations established in California almond orchards. Peak dispersal occurred in late July and early August during 1982 and 1983. Most predators (and spider mites) left the orchards on the prevailing winds from the northwest. Within the orchard, the prevailing winds had less influence, and dispersal was usually random. Both spider mites and predators dispersed randomly with regard to height from the almond trees, but data obtained during one 24-h interval suggest they do not disperse randomly throughout the day. Most aerial movements occurred between 16-22 h when relative humidity and wind speeds increased and temperatures decreased. Spider mites and predators were trapped on panels located 200 $\mathrm{m}$ from the orchara. A survey of carbaryl resistance levels in $M$. occidentalis collected from almond orchards surrounding the release sites indicates that carbaryl-resistant $M$. occidentalis dispersed at least $800 \mathrm{~m}$ between 1981-83. However, growers wishing to use the resistant strains should release them in their orchards as natural dispersal appears to be too slow. Migration of native $M$. occidentalis into the release sites appeared to be sufficiently rare that dilution of carbaryl-resistant populations was minimal during a 2-4 year period.
\end{abstract}

\section{Introduction}

Spider mites, and their phytoseiid predators that occur in deciduous crops, live in habitats that are discontinuous and seasonally transient. Thus, they must move from senescent foliage each fall to overwintering sites. They may also move from exhausted resources to new resources during the growing season. Both spider mites and their phytoseiid predators can walk from leaf to leaf or along the trunks of trees. Bernstein $(1983,1984)$ reviewed dispersal behavior of Phytoseiulus persimilis and showed that females could walk 319.5 meters per day. However, very rapid movements from orchard to orchard or from tree to tree have been observed. Apparently both spider mites and phytoseiids have adopted aerial movements as a long distance dispersal mechanism (Boykin \& Campbell, 1984; Brandenburg \& Kennedy, 1982; Field, 1981; Fleschner et al., 1956; Hoelscher, 1967; Hoy, 1982; Johnson \& Croft, 1976, 1981; Mitchell, 1970; Pedgley, 1982; Stabler, 1913).

Experiments were conducted in 2 almond orchards in California during 1982 and 1983 to answer the following questions: 1) Do spider mites and Metaseiulus occidentalis disperse aerially throughout the growing season? 2) Do spider mites and $M$. occidentalis disperse inside almond orchards from tree to tree via the prevailing winds from the northwest? 3) Do these mites enter and leave almond orchards randomly with regard to the four compass directions? 4) Is there a relationship 
between the number of $M$. occidentalis and spider mites on foliage and the number dispersing aerially? 5) Do spider mites and $M$. occidentalis disperse throughout the day? 6) Do predators and spider mites disperse primarily from the tops of almond trees? 7) How far can spider mites and predators disperse from almond orchards? 8) How do aerial movements of susceptible native $M$. occidentalis influence persistence of carbaryl resistance after the resistant strain has been established?

\section{Materials and methods}

Field plots. Experiments were conducted during 1982 and 1983 in 2 commercial almond orchards near Livingston, California in the San Joaquin Valley of California, U.S.A. The Livingston-I site is 5.7 hectares (14 acres) with Mono, Yosemite, and Mission varieties planted in a $1: 2: 1$ pattern, with trees $4.6 \mathrm{~m}$ and rows $7.6 \mathrm{~m}$ apart. $M$. occidentalis resistant to organophosphorus (OP) and carbaryl insecticides (Roush and Hoy, 1981) were released on 9 June 1981 into every third tree in every third row, by placing 350 우/release tree. During 1982, the grower applied carbaryl (4.5 kg $80 \mathrm{~W}$ P Sevin/ha) on May 14 and propargite on June $19(1.3 \mathrm{~kg} 30$ WP Omite/ha) by air blast sprayer. On August 4, he applied cyhexatin $(0.6 \mathrm{~kg} 30 \mathrm{WP}$ Plictran/ha) by aircraft. During 1983, he applied no insecticides during the growing season, but applied $0.6 \mathrm{~kg} 30$ WP propargite/ ha by air blast sprayer on June 9 .

The Livingston-III orchard consists of 18.2 ha (45 acres) of Mission, Nonpareil, and NePlus trees in a $1: 2: 1$ spacing with trees $7.3 \times 7.3 \mathrm{~m}$ apart. $M$. occidentalis resistant to carbaryl, OP, and sulfur pesticides (Hoy, in press) were released on $28 \mathrm{May}$ 1982, using 2 different release patterns; 900 우 / tree were released into every third tree in every third row in half the block (150000 우우), while 100 우우 were released into every tree in the other half of the block, using another 150000 우응 On 14 May and 15 July 1982, the grower applied carbaryl using $4.5 \mathrm{~kg}$ $80 \mathrm{WP} /$ ha and $6.8 \mathrm{~kg} 80 \mathrm{WP} / \mathrm{ha}$, respectively, with an air blast sprayer. On $15 \mathrm{July}$, the grower included $1.1 \mathrm{~kg} 30 \mathrm{WP}$ propargite/ ha with the carbaryl. During 1983, this block received no insecticides during the growing season, and the grower applied $1.1 \mathrm{~kg} 30 \mathrm{WP}$ propargite/ha on $10 \mathrm{June}$.
Foliage samples. During both years, foliage counts of spider mites and predators were obtained ca. weekly by removing 10 leaves/tree from the bottom half of each of 5 marked trees in 4-6 sites in the orchard (Fig. 1). The foliage was refrigerated, brushed with a mite brushing machine, and active stages of spider mites and $M$. occidentalis were counted under a dissecting microscope.

\section{Aerial sampling methods - 1982}

Movements into and out of orchards. Verticallyoriented clear plexiglass panels $(76 \times 175 \mathrm{~mm})$ were placed on towers 7.6 meters outside the 2 orchards to estimate the relative densities of mites moving into and out of the 2 orchards throughout the season in the 4 compass directions. Towers were placed on all 4 sides of the orchards, except none was placed on the north side of the Livingston-III block (Fig. 1). Panels were located 1.9, 3.9, and $5.8 \mathrm{~m}$ above ground level. Two panels at each height were directed toward and 2 away from the orchard, respectively. Each tower thus held 12 panels. Trees were estimated to be 8-9 $\mathrm{m}$ tall; thus the panels did not reach the canopy top. Panels were covered with a thin film of gear box oil (SAE 90) on one side only and replaced every week or 2 weeks. Mites trapped on the panels were counted using a dissecting microscope. After counting, the panels were washed and reused. Panels were continously present from May 5 until September 1 outside the Livingston-I site and from May 26 until August 11 outside the Livingston-III orchard.

Movements inside the orchards. Mite movement within the orchard was monitored over the season by hanging panels between rows with a rope and pulley system so that the grower could take his farm equipment down the rows. Panels were changed each week or 2 weeks and examined as described above. Two sets of 4 panels each were ca. 4.8 and 2.8 $\mathrm{m}$ above ground level, and were oriented so that all 4 compass directions were sampled at mid-and lower-canopy heights.

The mean number of spider mites (active stages only) and $M$. occidentalis on foliage was compared to the number of mites captured on the plexiglass panels located inside the 2 orchards. To compare 

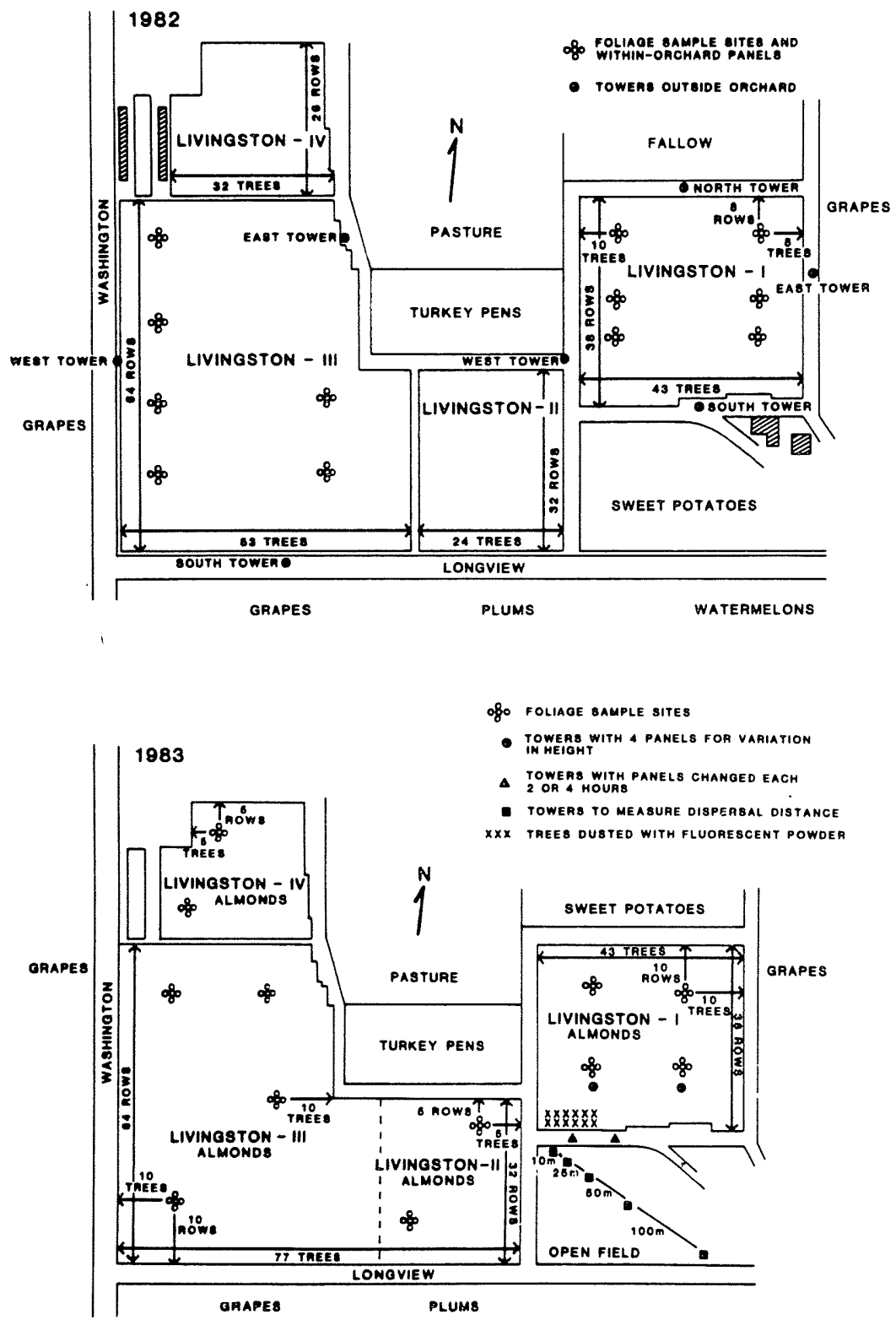

Fig. 1. Map of Livingston-I and Livingston-III almond orchards and surrounding area with foliage sample sites, and panel locations within and without the 2 orchards in 1982 (top) and 1983 (bottom).

the mean number of mites on foliage with those on the panels, the number on the panel was divided by 7.5 , as this is the approximate ratio between an almond leaf and the panel.

\section{Aerial sampling methods -1983}

Greased panels were placed inside and outside the Livingston-I orchard during July $18-25$ and
July 25 -August 1 . Clear perspex sheets $(122 \times 49.5$ $\mathrm{cm}\left(0.604 \mathrm{~m}^{2}\right)$ ) were nailed to wooden frames and coated with a thin film of gear box oil (SAE 140) on one side only using a $15.2 \mathrm{~cm}$ rubber roller (Printmaster). Panels of the same size were used once in each of the 3 experiments described below, as after removal they were cut into 40 strips each $3 \times 49.5$ $\mathrm{cm}$ and spider mites and predators were counted using a dissecting microscope. 
Diurnal patterns of dispersal. To learn if mites disperse randomly during the day, a panel was placed on each of 2 towers $6.1 \mathrm{~m}$ tall. The towers were located $8 \mathrm{~m}$ south of the first row of trees (Fig. 1); a panel extended down $1.22 \mathrm{~m}$ from the top of the tower with the greased side oriented towards the orchard. Panels were replaced every $2 \mathrm{~h}$ for $24 \mathrm{~h}$ during July $18-19$ and every $4 \mathrm{~h}$ for $48 \mathrm{~h}$ during July 25-27. Every time the panels were changed, weather data (temperature, relative humidity, wind speed, and wind direction) were collected.

Variability in numbers collected at different heights. During 1982, the panels suspended at 2 heights within the orchard did not sample the canopy top. Since dispersing spider mites and scale insects are positively phototropic and negatively geotropic(Washburn \& Washburn, 1984), we wondered if $M$. occidentalis dispersed from the tree tops. To test this, 4 perspex panels were placed 2.8 , $4.6,7.3$, and $10.8 \mathrm{~m}$ above ground level on each of 2 towers inside the Livingston-I orchard. The towers were located between 2 rows of trees (Fig. 1). The panel located $7.3 \mathrm{~m}$ above ground level was near and the panel $10.8 \mathrm{~m}$ above ground was above the canopy. Panels were oriented so that the greased surface faced northwest (in the direction of the prevailing winds), were left in the orchard for 7 days, and replaced once for a second week of trapping.

Dispersal distance. Two rows of 5 trees in the southwest corner of the Livingston-I 'orchard were dusted with fluorescent powder according to the method described by Brandenburg \& Kennedy (1982). Dust $(0.9 \mathrm{~kg})$ was applied twice, once a week, using a 2-stroke powder duster. Spider mites and $M$. occidentalis trapped on the greased panels during the subsequent week were examined for the dust using an UV light. Because the mites were inadequately' marked the panels were cut in strips and the mites were counted under dissecting microscope. Mites were trapped on 5 panels, each placed vertically $6.1 \mathrm{~m}$ above the ground on a tower, with the panel extending downward $122 \mathrm{~cm}$. The 5 towers were placed in a diagonal line across an open field and were $15,25,50,100$, and $200 \mathrm{~m}$ southeast of the dusted trees (Fig. 1).
Survey for carbaryl resistance in surrounding almond orchards. Almond orchards surrounding the Livingston release sites (Fig. 1) were examined during July 19-26, 1983 for M. occidentalis to obtain colonies that could be tested for their carbaryl resistance levels. Since native $M$. occidentalis colonies characteristically exhibit no carbaryl resistance, the presence of even low levels of carbaryl resistance in these colonies would support the hypothesis that the resistant strain has dispersed from the release sites into surrounding orchards (Hoy, 1982; Roush, 1979; Roush \& Hoy, 1981; Hoy, unpubl.). Fifteen colonies were obtained from sites within a radius of $4827 \mathrm{~m}$ ( 3 miles) with founding numbers ranging from 3 to 26 , averaging 10 individuals. The colonies were kept until 40-50 gravid 우우 could be tested, $5 /$ disc, on pinto bean leaf discs (Phaseolus vulgaris), sprayed with $2.4 \mathrm{~g}$ a.i. carbaryl/1 distilled water. The carbaryl-OP resistant laboratory colony and a carbaryl-susceptible laboratory colony (WA-33 or Immature Selection-37) were tested at the same time as controls. Susceptible colonies, whether freshly collected from the field or maintained in the laboratory, typically have $0-4 \%$ survival rates at this test dose, while the resistant colony typically has a $70-85 \%$ survival rate. In addition, 20 우 from each colony were tested with water as a check of handling mortality or disease.

Survival of M. occidentalis at high temperatures. Previous laboratory and field studies indicated that hungry, newly-mated $M$. occidentalis females are the primary dispersants (Field, 1981; Hoy, 1982, unpubl.) Dispersing predator $\$ \circ$ must survive high temperatures and low relative humidities in the San Joaquin Valley during July and August, and we wondered how long they could survive these harsh conditions. Female deutonymphs of the carbaryl$O P$-sulfur resistant colony were individually isolated with a $\hat{\sigma}$ on senescing pinto bean leaf discs densely populated with $T$. urticae as prey. As soon as the 우 mated, they were moved to a paraffincoated paper disc without prey for $24 \mathrm{~h}$ at $25^{\circ} \mathrm{C}$ and $60-70 \%$ R.H. Five hungry 우우 were slide-mounted ventral side up on sticky tape using the method developed for toxicity tests (described by Hoy \& Knop, 1979), and placed into a temperature cabinet (Percival I-30 B) and held 12, 24, 36, and $48 \mathrm{~h}$ at 
$30^{\circ} \mathrm{C}$ and $6 \mathrm{~h}$ at $35^{\circ}$ and $40^{\circ} \mathrm{C}$. Each temperature and duration was replicated 4 or 5 times (20 or 25 우 total) for each temperature and duration tested. Equal numbers of $q Q$ were used as controls at each temperature and duration but placed into boxes with $80-90 \%$ R.H. The proportion surviving was recorded at the end of each test interval. as once the 우 were placed in the desiccator it was not opened until time to score.

\section{Results and discussion}

Movements out of orchards in 1982. Three species of spider mites were trapped on panels outside the 2 orchards in 1982. They were Tetranychus pacificus (relative abundance $=$ ca. $60 \%), T$. urticae $(10 \%)$, and Panony'chus ulmi (30\%).
Both spider mites and $M$. occidentalis left the Livingston-I orchard primarily on the south and east sides of the orchard throughout the season (Table 1). Ca. $92 \%$ of the spider mites and $94 \%$ of the predators were trapped on panels outside the Livingston-I orchard on the south and east towers. Similarly, 96 and $82 \%$ of the spider mites and $M$. occidentalis, respectively, were trapped on the panels located on the south and east towers outside the Livingston-III orchard (Table 2). During the summer the prevailing winds in this area of the San Joaquin Valley are from the northwest; thus, it appears that much of the aerial dispersal of both spider mites and $M$. occidentalis out of these 2 orchards is via the prevailing winds. More than $80 \%$ of the spider mites and predators trapped on the greased panels were adult $ㅇ$. There were no consistent statistical differences in the numbers of mites

Tahle 1. Spider mites and M. occidentalis leaving the Livingston-I orchard, 1982.

\begin{tabular}{|c|c|c|c|c|c|c|c|c|}
\hline \multirow{3}{*}{$\begin{array}{l}\text { Date panels } \\
\text { placed on } \\
\text { tovers } \\
1982 \\
\text { May } 5\end{array}$} & \multicolumn{4}{|c|}{$\begin{array}{c}\text { Hean spider altes (S.D.) trapped/panel } \\
\text { located on the }\end{array}$} & \multicolumn{4}{|c|}{ Mean $\underline{M} \cdot \frac{\text { occidentalls }}{\text { panel located on the }}$} \\
\hline & North & $\begin{array}{l}\text { South } \\
\text { side of the }\end{array}$ & $\begin{array}{l}\text { East } \\
\text { orchard } 1 \text { I }\end{array}$ & West & North & $\begin{array}{l}\text { South } \\
\text { side of the }\end{array}$ & $\begin{array}{l}\text { East } \\
\text { orchard1/ }\end{array}$ & West \\
\hline & $\begin{array}{c}0 \\
(0)\end{array}$ & - & - & - & $\begin{array}{c}0 \\
(0)\end{array}$ & - & - & - \\
\hline 11 & $\begin{array}{c}0.3 \\
(0.8)\end{array}$ & - & - & 0 & $\begin{array}{c}0 \\
(0)\end{array}$ & - & $\infty$ & - \\
\hline 19 & $\begin{array}{c}0 \\
(0)\end{array}$ & $\begin{array}{c}0 \\
(0)\end{array}$ & $\begin{array}{c}0 \\
(0)\end{array}$ & $\begin{array}{c}0 \\
(0)\end{array}$ & $\begin{array}{c}0 \\
(0)\end{array}$ & $\begin{array}{c}0 \\
(0)\end{array}$ & $\begin{array}{c}0 \\
(0)\end{array}$ & $\begin{array}{c}0 \\
(0)\end{array}$ \\
\hline June 2 & $\begin{array}{c}0 \\
(0)\end{array}$ & $\begin{array}{l}0.2 \\
(0.4)\end{array}$ & $\begin{array}{c}0 \\
(0)\end{array}$ & $\begin{array}{c}0.2 \\
(0.4)\end{array}$ & $\begin{array}{c}0 \\
(0)\end{array}$ & $\begin{array}{c}0 \\
(0)\end{array}$ & $\begin{array}{c}0 \\
(0)\end{array}$ & $\begin{array}{c}0 \\
(0)\end{array}$ \\
\hline 16 & $\begin{array}{l}0.2 \\
(0.4)\end{array}$ & $\begin{array}{l}0.2 \\
(0.4)\end{array}$ & $\begin{array}{c}0 \\
(0)\end{array}$ & $\begin{array}{c}0 \\
(0)\end{array}$ & $\begin{array}{c}0 \\
(0)\end{array}$ & $\begin{array}{c}0 \\
(0)\end{array}$ & $\begin{array}{c}0 \\
(0)\end{array}$ & $\begin{array}{c}0 \\
(0)\end{array}$ \\
\hline July 72 & $\begin{array}{l}0.5 b \\
(0.8)\end{array}$ & $\begin{array}{r}2.5 \mathrm{a} \\
(2.4)\end{array}$ & $\begin{array}{l}0.5 b \\
(0.8)\end{array}$ & $\begin{array}{l}0.2 b \\
(0.4)\end{array}$ & $\begin{array}{c}0 \\
(0)\end{array}$ & $\begin{array}{c}0.2 \\
(0.4)\end{array}$ & $\begin{array}{c}0 \\
(0)\end{array}$ & $\begin{array}{c}0 \\
(0)\end{array}$ \\
\hline $14^{2}$ & $\begin{array}{l}3.2 \mathrm{~b} \\
(0.9)\end{array}$ & $\begin{array}{r}73.3 a \\
(42.0)\end{array}$ & $\begin{array}{r}8.7 b \\
(3.6)\end{array}$ & $\begin{array}{r}8.7 b \\
(2.7)\end{array}$ & $\begin{array}{c}0.8 \\
(0.9)\end{array}$ & $\begin{array}{c}1.3 \\
(1.4)\end{array}$ & $\begin{array}{c}0.3 \\
(0.5)\end{array}$ & $\begin{array}{c}0 \\
(0)\end{array}$ \\
\hline $28^{2}$ & - & $\begin{array}{l}104.8 \mathrm{a} \\
(36.2)\end{array}$ & $\begin{array}{r}7.7 b \\
(4.4)\end{array}$ & $\begin{array}{r}6.8 \mathrm{~b} \\
(2.1)\end{array}$ & - & $\begin{array}{r}2.8 a \\
(2.0)\end{array}$ & $\begin{array}{l}0.8 b \\
(0.4)\end{array}$ & $\begin{array}{l}0.5 b \\
(0.8)\end{array}$ \\
\hline Aug. $4^{2}$ & $\begin{array}{l}1.5 b \\
(1.4)\end{array}$ & $\begin{array}{l}100.78 \\
(76.3)\end{array}$ & $\begin{array}{l}5.3 \mathrm{~b} \\
(2.1)\end{array}$ & $\begin{array}{l}3.0 \mathrm{~b} \\
(2.8)\end{array}$ & $\begin{array}{l}0.2 b \\
(0.4)\end{array}$ & $\begin{array}{r}5.3 a \\
(3.8)\end{array}$ & $\begin{array}{r}2.0 \mathrm{~b} \\
(1.4)\end{array}$ & $\begin{array}{l}0.2 b \\
(0.4)\end{array}$ \\
\hline $11^{2}$ & $\begin{array}{l}0.3 \\
(0.5)\end{array}$ & $\begin{array}{c}9.0 \\
(3.1)\end{array}$ & $\begin{array}{l}10.3 \\
(12.5)\end{array}$ & $\begin{array}{l}0.2 \\
(0.4)\end{array}$ & $\begin{array}{c}0 b \\
(0)\end{array}$ & $\begin{array}{r}9.8 \mathrm{a} \\
(1.5)\end{array}$ & $\begin{array}{r}10.7 \mathrm{a} \\
(13.4)\end{array}$ & $\begin{array}{l}0.2 b \\
(0.4)\end{array}$ \\
\hline $20^{2}$ & $\begin{array}{c}o b \\
(0)\end{array}$ & $\begin{array}{l}4.000 \\
(2.5)\end{array}$ & $\begin{array}{r}0.8 \mathrm{~b} \\
(2.1)\end{array}$ & $\begin{array}{c}\mathrm{ob} \\
(0)\end{array}$ & $\begin{array}{c}\text { Ob } \\
(0)\end{array}$ & $\begin{array}{l}1.0 \mathrm{a} \\
(0.7)\end{array}$ & $\begin{array}{l}0.2 b \\
(0.4)\end{array}$ & $\begin{array}{c}0 b \\
(0)\end{array}$ \\
\hline
\end{tabular}

1 Mites trapped on 6 panels ( $175 \times 75 \mathrm{ma}$ ) facing the orchard on towers at each site.

2 Means significantly different at the $5 \%$ level when tested with one way ANOVA. 
Table 2. Spider mites and $M$. occidentalis leaving the Livingston III-orchard.

\begin{tabular}{|c|c|c|c|c|c|c|c|}
\hline \multirow{2}{*}{\multicolumn{2}{|c|}{$\begin{array}{l}\text { Date panels } \\
\text { placed on } \\
\text { towers } \\
1982\end{array}$}} & \multicolumn{3}{|c|}{$\begin{array}{c}\text { Mean spider altes (S.D.) trapped/ } \\
\text { panel located on the } \\
\end{array}$} & \multicolumn{3}{|c|}{$\begin{array}{l}\text { Mean } \underline{M} \cdot \frac{\text { occidentalls }}{\text { panel located on the }} \text { (S.D.) trapped/ } \\
\end{array}$} \\
\hline & & \multicolumn{3}{|c|}{$\begin{array}{l}\text { South } \\
\text { Easte of the orchard } 1\end{array}$} & \multicolumn{3}{|c|}{$\begin{array}{c}\text { South } \\
\text { side of the orchard }{ }^{1}\end{array}$} \\
\hline May 2 & 26 & $\begin{array}{c}0.3 \\
(0.8)\end{array}$ & $\begin{array}{c}0.3 \\
(0.8)\end{array}$ & $\begin{array}{c}0 \\
(0)\end{array}$ & $\begin{array}{c}0 \\
(0)\end{array}$ & $\begin{array}{c}0 \\
(0)\end{array}$ & $\begin{array}{c}0 \\
(0)\end{array}$ \\
\hline June & 2 & $\begin{array}{l}0.2 \\
(0.4)\end{array}$ & $\begin{array}{l}0.2 \\
(0.4)\end{array}$ & $\begin{array}{c}0 \\
(0)\end{array}$ & $\begin{array}{c}0 \\
(0)\end{array}$ & $\begin{array}{c}0 \\
(0)\end{array}$ & $\begin{array}{c}0 \\
(0)\end{array}$ \\
\hline & 16 & $\begin{array}{l}0.3 \\
(0.5)\end{array}$ & $\begin{array}{l}0.3 \\
(0.5)\end{array}$ & $\begin{array}{c}0.2 \\
(0.4)\end{array}$ & $\begin{array}{c}0 \\
(0)\end{array}$ & $\begin{array}{c}0 \\
(0)\end{array}$ & $\begin{array}{c}0 \\
(0)\end{array}$ \\
\hline & $23^{2,3}$ & $\begin{array}{r}8.0 \mathrm{a} \\
(2.1)\end{array}$ & $\begin{array}{l}2.2 b \\
(2.1)\end{array}$ & $\begin{array}{l}0.8 \mathrm{~b} \\
(1.5)\end{array}$ & $\begin{array}{l}0.2 \\
(0.4)\end{array}$ & $\begin{array}{c}0 \\
(0)\end{array}$ & $\begin{array}{c}0 \\
(0)\end{array}$ \\
\hline July & $1^{2}$ & $\begin{array}{r}34.2 a \\
(30.9)\end{array}$ & $\begin{array}{l}6.8 \mathrm{~b} \\
(3.3)\end{array}$ & $\begin{array}{l}1.0 \mathrm{~b} \\
(0.6)\end{array}$ & $\begin{array}{c}0 \\
(0)\end{array}$ & $\begin{array}{l}0.2 \\
(0.4)\end{array}$ & $\begin{array}{c}0 \\
(0)\end{array}$ \\
\hline & $7^{2}$ & $\begin{aligned} 58.0 \mathrm{a} \\
(43.2)\end{aligned}$ & $\begin{array}{l}19.2 \mathrm{~b} \\
(9.7)\end{array}$ & $\begin{array}{l}1.7 b \\
(2.2)\end{array}$ & $\begin{array}{c}0 \\
(0)\end{array}$ & $\begin{array}{c}0 \\
(0)\end{array}$ & $\begin{array}{c}0 \\
(0)\end{array}$ \\
\hline & $14^{2}$ & $\begin{array}{r}61.2 a \\
(32.3)\end{array}$ & $\begin{array}{r}78.7 \mathrm{a} \\
(28.4)\end{array}$ & $\begin{array}{r}4.3 b \\
(3.8)\end{array}$ & $\begin{array}{r}6.7 a \\
(3.9)\end{array}$ & $\begin{array}{r}2.0 \mathrm{~b} \\
(2.3)\end{array}$ & $\begin{array}{c}\mathrm{Ob} \\
(0)\end{array}$ \\
\hline & $21^{2}$ & $\begin{array}{l}66.3 \mathrm{~b} \\
(42.1)\end{array}$ & $\begin{array}{l}196.0 a \\
(47.0)\end{array}$ & $\begin{array}{r}2.8 \mathrm{~b} \\
(2.5)\end{array}$ & $\begin{array}{l}13.3 \mathrm{ab} \\
(8.7)\end{array}$ & $\begin{array}{l}7.0 \mathrm{a} \\
(3.5)\end{array}$ & $\begin{array}{l}0.2 \mathrm{bc} \\
(0.4)\end{array}$ \\
\hline & $28^{2}$ & $\begin{array}{c}29.8 \mathrm{~b} \\
(24.6)\end{array}$ & $\begin{array}{r}693.0 a \\
(324.2)\end{array}$ & $\begin{array}{r}27.0 \mathrm{~b} \\
(16.0)\end{array}$ & $\begin{array}{r}22.2 \mathrm{~b} \\
(17.1)\end{array}$ & $\begin{array}{l}101.5 a \\
(21.4)\end{array}$ & $\begin{array}{r}5.2 b \\
(4.1)\end{array}$ \\
\hline Aug. & 11 & $\begin{array}{l}0.8 \\
(1.5)\end{array}$ & $\begin{array}{l}1.0 \\
(1.0)\end{array}$ & $\begin{array}{l}0.8 \\
(1.2)\end{array}$ & $\begin{array}{l}0.5 \\
(0.5)\end{array}$ & $\begin{array}{l}2.3 \\
(1.8)\end{array}$ & $\begin{array}{c}0 \\
(0)\end{array}$ \\
\hline
\end{tabular}

1 Mites were trapped on 6 panels $(175 \times 75 \mathrm{~m})$ facing the orchard on towers at each site.

2 Means signiflcantly different at the $5 z$ level when tested with one way ANOVA.

3 Splder mite means of June 23 were transformed to $108(n+1)$ due to a lack of homogene1ty of variances.

trapped on the panels at the 3 heights on the towers outside the orchard, so the data are pooled in $\mathrm{Ta}$. bles 1 and 2 .

The correlation coefficient for the number of spider mites on foliage (all active stages) vs. the number trapped on the panels (primarily adult females) is 0.609 (S.E. $=25.93, \mathrm{P} \leqslant 0.001$ ) for the Livingston-I orchard and 0.308 (S.E. $=10.00, \mathrm{P} \leqslant$ 0.001 ) for the Livingston-III orchard. Few spider mites were trapped until after early July (Tables 1, 2, Fig. 2). The fact that aerial dispersal peaked in July in both orchards, even though spider mite densities were different, suggests that factors other than density may also influence aerial dispersal. One such factor could be the almond tree physiology. For example, hullsplit typically occurs during the first week of July in San Joaquin Valley almonds and this major event could be associated with substantial phy'siological changes in the foliage.

Dispersal of M. occidentalis was correlated with the density of active stages of predators on the foliage in the Livingston-I almond orchard $(r=$ 0.619, S.E. $=1.6$ ). Peak density of Po on the panels lagged behind the peak density on the foliage by about one week (Table 1). The correlation between the numbers of predators on foliage and on the panels was lower in the Livingston-III orchard $(r=$ 0.067 , S.E. $=1.487$ ). Little dispersal occurred in this orchard until July 21 , whereas densities on the foliage were high during late June and early July (Table 2). The lag in the numbers of predators trapped on paneis could be due in part to the fact that nymphs as well as adults were sampled on foliage while $\$$ primarily were trapped on the panels. 

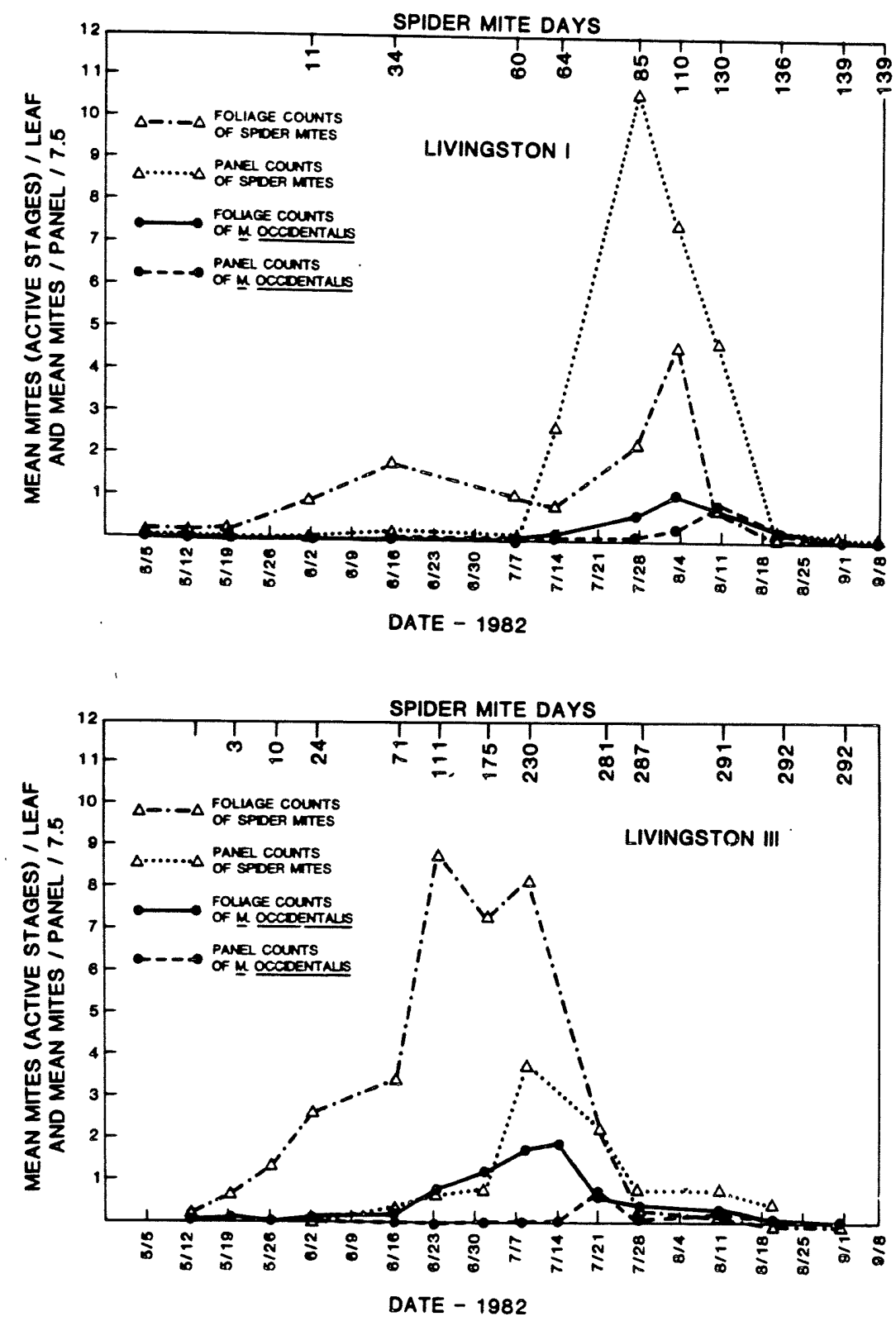

Fig. 2. Comparison of mean number spider mites and $M$. occidentalis on foliage (active stages) and on greased panels (primarily females) in the Livingston-l (top) and III (bottom) orchards during 1982. No. mites on panels divided by 7.5 to correspond to almond leaf area.

Large numbers of spider mites left the 2 orchards during 1982 (Tables 1, 2). To obtain a conservative estimate of the number of spider mites and predators leaving each side of the orchard over the season, we assumed a) that the number of mites trapped on the small panels $(76 \times 175 \mathrm{~mm})$ were directly proportional to the number leaving the surface area of the side of the orchard and 5) that the number leaving the top of the orchard was negligible (which is unlikely). If these assumptions are followed then about 170 million spider mites left the Livingston-I orchard over the season on the south side of this 5.7 ha orchard, which measured $196.6 \times 3.7 \mathrm{~m}$ in length and height, and 30 million 
left on the east side of the orchard, for a total of 200 million spider mites. Using the same assumptions, an estimated 230 and 1100 million spider mites left the south and east sides, respectively, of the 18.2 ha Livingston-III orchard during 1982. These numbers could be sufficiently high to have an impact on certain surrounding orchards and vineyards if even $10 \%$ of the dispersing spider mites colonize a new site successfully. Thus, orchards or vineyards lacking predators and having low numbers of spider mites could be inoculated with spider mites.

These numbers are low estimates of spider mite dispersal, since it is not unusual for San Joaquin Valley almond orchards to have peak densities reaching 30-40/leaf in contrast to the peak of 9-11 in these 2 sites. Stabler (1913) showed that spider mites dispersed at least $200 \mathrm{~m}$ from almond orchards and he 'established the fact that red spiders are blown sufficient distances by the wind to make an infested orchard a menace to orchards within a reasonable distance.' Likewise, Brandenburg \& Kennedy (1982) showed that 'Large populations of spider mites in field corn were found responsible for subsequent infestations in peanuts,' when these fields were adjacent.

However, it is likely that 200 or even 1100 million spider mites is only a small proportion of the total number of spider mites in many orchards or vineyards under normal circumstances. If we conservatively assume that over the season each leaf has only one spider mite, estimate that each almond tree has about 0.5 million leaves, there are 75 trees/acre, then an almond orchard might conservatively have 37.5 million spider mites/acre over a season. Under many circumstances the arrival of additional spider mites would probably be unnoticed. However, aerial inoculation might be very important if the mites coming into the orchard have a unique pesticide resistance, or if the orchard lacks predators and/or has very low densities of spider mites due to pesticide applications.

Using the same assumptions regarding aerial movements, approximately 8.1 and 8.3 million $M$. occidentalis left the south and east sides of the Livingst on-I orchard over the season, respectively. Similarly, about 40 and 97 million predators left the larger Livingston-III orchard during 1982. These predators could provide an inoculum for surrounding orchards or vineyards if survival is high and the dispersal distances achieved are sufficient.
Again, however, the impact on the recipient orchard will depend upon the relative densities of the resident predator population. If the orchard lacks predators, immigration of the resistant strain could be significant. If the recipient orchard has high densities of susceptible native predators then the gene frequency of the resistance gene would remain very small unless relevant pesticides were used as a selective agent.

Movements into the orchards in 1982. The panels with the greased surfaces facing away from the orchard nearly always trapped significantly fewer mites than the traps facing the orchard on the same dates during 1982. Thus, there appears to be 2.5 to 28 -fold difference in the number of $M$. occidentalis entering and leaving the Livingston-I orchard over the season. The total number of $M$. occidentalis presumably entering the orchard that was trapped on the 6 panels facing away from the south side of the Livingston-I orchard was 22; 2 were trapped on panels facing west, none on panels facing north, and 3 were trapped on panels facing east over the season. In contrast, a total of $103,5,6$, and 84 females were trapped on panels facing toward the south, west, north, and east sides of the orchard, respectively, and presumably represent the proportion leaving the orchard. These data suggest that relatively few pesticide-susceptible $M$. occidentalis entered the Livingston-I orchard. Similar results were obtained with the Livingston-III orchard, where the number leaving apparently outnumbered the number entering by ratios of 3.8 to $8.4 . \mathrm{M}$. occidentalis were trapped on panels facing away from the orchard on the south, west, and east of Livingston-III in the following numbers: 71,39 , and 68 , suggesting these mites were entering the orchard. In contrast, 276, 163, and 569 predators left this orchard over the 1982 season and were trapped on the panels on the south, west, and east sides of the orchard, respectively.

There is however, a correlation between the number of predators trapped on the panels facing toward and away from the orchard at each of the tower sites (compass directions). Thus, if high densities left the orchard on the south side of the orchard, comparably high numbers were trapped on panels facing away from the orchard. These traps were used to estimate the number of predators entering the orchard. If the mites disperse primarily 
on the prevailing winds, then proportionally more should have been trapped on the panels facing north and west. This suggests that the traps facing away from the orchard actually measure the relative densities of predators in the air at the time, and the number impinging on the panels facing away from the orchard are not a reliable estimator of the number actually coming into the orchard. We sus- pect that eddy effects allowed outgoing predators (and spider mites) to be trapped on the panels facing a way from the orchard, thus overestimating the numbers entering the orchard from distant orchards or vineyards.

Movements inside the orchards. The traps suspended between 2 rows of trees within the 2 Living-

Table 3. Movement of spider mites and M. occidentalis with the Livingston-I almond orchard during 1982.

\begin{tabular}{|c|c|c|c|c|c|c|c|c|}
\hline \multirow{2}{*}{$\begin{array}{l}\text { Date panels } \\
\text { placed on } \\
\text { towers } \\
1982\end{array}$} & \multicolumn{4}{|c|}{$\begin{array}{l}\text { Mean oplder mites (S.D.) trapped/panel } \\
\text { facing }\end{array}$} & \multicolumn{4}{|c|}{ Mean $\frac{M . \text { occidentalls }}{\text { panel facing }}\left(S . D_{0}\right)$ trapped/ } \\
\hline & North & South & Ea 8t & West ${ }^{1}$ & North & South & E88t & West \\
\hline Apr。 22 & - & - & $\begin{array}{c}0 \\
(0)\end{array}$ & $\begin{array}{c}0 \\
(0)\end{array}$ & - & - & $\begin{array}{c}0 \\
(0)\end{array}$ & $\begin{array}{c}0 \\
(0)\end{array}$ \\
\hline 28 & $\begin{array}{c}0 \\
(0)\end{array}$ & $\begin{array}{c}0 \\
(0)\end{array}$ & $\begin{array}{c}0 \\
(0)\end{array}$ & $\begin{array}{c}0 \\
(0)\end{array}$ & $\begin{array}{c}0 \\
(0)\end{array}$ & $\begin{array}{c}0 \\
(0)\end{array}$ & $\begin{array}{c}0 \\
(0)\end{array}$ & $\begin{array}{c}0 \\
(0)\end{array}$ \\
\hline May 5 & $\begin{array}{c}0.3 \\
(1.0)\end{array}$ & $\begin{array}{c}0.9 \\
(3.2)\end{array}$ & $\begin{array}{c}0.1 \\
(0.3)\end{array}$ & $\begin{array}{c}0.1 \\
(0.5)\end{array}$ & $\begin{array}{c}0 \\
(0)\end{array}$ & $\begin{array}{c}0 \\
(0)\end{array}$ & $\begin{array}{c}0 \\
(0)\end{array}$ & $\begin{array}{c}0 \\
(0)\end{array}$ \\
\hline 11 & $\begin{array}{c}0 \\
(0)\end{array}$ & $\begin{array}{c}0 \\
(0)\end{array}$ & $\begin{array}{c}0 \\
(0.2)\end{array}$ & $\begin{array}{c}0 \\
(0.2)\end{array}$ & $\begin{array}{c}0 \\
(0)\end{array}$ & $\begin{array}{c}0 \\
(0)\end{array}$ & $\begin{array}{c}0 \\
(0)\end{array}$ & $\begin{array}{c}0 \\
(0)\end{array}$ \\
\hline 19 & $\begin{array}{c}0 \\
(0)\end{array}$ & $\begin{array}{c}0 \\
(0.2)\end{array}$ & $\begin{array}{c}0 \\
(0.2)\end{array}$ & $\begin{array}{c}0 \\
(0.2)\end{array}$ & $\begin{array}{c}0.1 \\
(0.3)\end{array}$ & $\begin{array}{c}0 \\
(0.2)\end{array}$ & $\begin{array}{c}0 \\
(0)\end{array}$ & $\begin{array}{c}0 \\
(0)\end{array}$ \\
\hline June 2 & $\begin{array}{l}2.2 \\
(1.9)\end{array}$ & $\begin{array}{c}2.7 \\
(4.0)\end{array}$ & $\begin{array}{l}1.7 \\
(1.7)\end{array}$ & $\begin{array}{c}2.2 \\
(1.5)\end{array}$ & $\begin{array}{c}0 \\
(0)\end{array}$ & $\begin{array}{c}0 \\
(0)\end{array}$ & $\begin{array}{c}0 \\
(0)\end{array}$ & $\begin{array}{c}0 \\
(0)\end{array}$ \\
\hline 16 & $\begin{array}{c}1.8 \\
(2.2)\end{array}$ & $\begin{array}{l}1.4 \\
(1.8)\end{array}$ & $\begin{array}{c}0.8 \\
(1.2)\end{array}$ & $\begin{array}{l}1.3 \\
(1.4)\end{array}$ & $\begin{array}{c}0 \\
(0)\end{array}$ & $\begin{array}{c}0 \\
(0)\end{array}$ & $\begin{array}{c}0 \\
(0)\end{array}$ & $\begin{array}{c}0 \\
(0)\end{array}$ \\
\hline Ju1y $7^{2}$ & $\begin{array}{c}23.0 \\
(22.6)\end{array}$ & $\begin{array}{c}16.3 \\
(19.3)\end{array}$ & $\begin{array}{c}19.5 \\
(22.9)\end{array}$ & $\begin{array}{c}24.6 \\
(28.1)\end{array}$ & $\begin{array}{l}0.4 \mathrm{ab} \\
(1.1)\end{array}$ & $\begin{array}{l}0.2 \mathrm{ab} \\
(0.8)\end{array}$ & $\begin{array}{c}0 \mathrm{~b} \\
(0.9)\end{array}$ & $\begin{array}{r}0.7 a \\
(0.9)\end{array}$ \\
\hline $14^{2}$ & $\begin{array}{c}66.2 \\
(83.3)\end{array}$ & $\begin{array}{c}63.4^{\circ} \\
(90.5)\end{array}$ & $\begin{array}{c}66.3 \\
(101.3)\end{array}$ & $\begin{array}{c}80.3 \\
(116.8)\end{array}$ & $\begin{array}{l}0.7 \mathrm{ab} \\
(1.1)\end{array}$ & $\begin{array}{r}0.3 \mathrm{~b} \\
(0.9)\end{array}$ & $\begin{array}{c}0.2 b \\
(1.0)\end{array}$ & $\begin{array}{l}1.0 \mathrm{a} \\
(1.1)\end{array}$ \\
\hline $28^{3}$ & $\begin{array}{c}58.5 \\
(80.2)\end{array}$ & $\begin{array}{c}48.3 \\
(43.8)\end{array}$ & $\begin{array}{c}50.5 \\
(67.1)\end{array}$ & $\begin{array}{c}75.0 \\
(108.7)\end{array}$ & $\begin{array}{c}3.0 \\
(3.4)\end{array}$ & $\begin{array}{c}2.5 \\
(2.8)\end{array}$ & $\begin{array}{c}2.5 \\
(3.0)\end{array}$ & $\begin{array}{c}2.7 \\
(3.1)\end{array}$ \\
\hline Aug. 42,3 & $\begin{array}{c}44.5 \\
(56.4)\end{array}$ & $\begin{array}{c}25.6 \\
(21.1)\end{array}$ & $\begin{array}{c}32.7 \\
(25.0)\end{array}$ & $\begin{array}{c}44.1 \\
(57.0)\end{array}$ & $\begin{array}{r}8.1 a \\
(6.7)\end{array}$ & $\begin{array}{r}5.8 c \\
(5.5)\end{array}$ & $\begin{array}{l}6.5 b c \\
(6.8)\end{array}$ & $\begin{array}{l}7.0 \mathrm{ab} \\
(6.7)\end{array}$ \\
\hline $11^{2,3}$ & $\begin{array}{r}2.0 \mathrm{a} \\
(1.9)\end{array}$ & $\begin{array}{r}1.0 \mathrm{~b} \\
(1.1)\end{array}$ & $\begin{array}{l}1.6 \mathrm{ab} \\
(1.9)\end{array}$ & $\begin{array}{l}1.8 \mathrm{ab} \\
(2.1)\end{array}$ & $\begin{array}{r}3.6 a \\
(3.1)\end{array}$ & $\begin{array}{r}1.3 b \\
(2.5)\end{array}$ & $\begin{array}{r}1.3 b \\
(2.1)\end{array}$ & $\begin{array}{c}4.0 \mathrm{a} \\
(3.2)\end{array}$ \\
\hline $20^{3}$ & $\begin{array}{c}1.8 \\
(4.3)\end{array}$ & $\begin{array}{c}0.3 \\
(0.8)\end{array}$ & $\begin{array}{c}0.4 \\
(1.0)\end{array}$ & $\begin{array}{c}1.8 \\
(4.3)\end{array}$ & $\begin{array}{c}0.6 \\
(1.3)\end{array}$ & $\begin{array}{c}0.3 \\
(1.0)\end{array}$ & $\begin{array}{c}0.3 \\
(0.8)\end{array}$ & $\begin{array}{c}0.3 \\
(0.9)\end{array}$ \\
\hline Sept. $1^{3}$ & $\begin{array}{l}0.4 \\
(1.0)\end{array}$ & $\begin{array}{c}0.2 \\
(0.5)\end{array}$ & $\begin{array}{c}0.2 \\
(0.5)\end{array}$ & $\begin{array}{c}0.3 \\
(0.7)\end{array}$ & $\begin{array}{c}0 \\
(0.2)\end{array}$ & $\begin{array}{c}0 \\
(0.2)\end{array}$ & $\begin{array}{c}0 \\
(0.2)\end{array}$ & $\begin{array}{c}0.1 \\
(0.3)\end{array}$ \\
\hline
\end{tabular}

1 Mites were trapped on 16 panels (175 × $75 \mathrm{~mm})$ at each of 6 sites; at each 81 te, 4 panels each faced north, south, east and rest.

2 Means significantly different at the $5 \%$ level when tested with a one way ANOVA.

3 Spider ate counts during July 28-Sept. 1 were tested using $\log (n+1)$ transformation due to lack of homogenelty of varlance. 
ston orchards during 1982 were located at 2 heights and oriented to trap mites coming from all 4 compass directions. Unlike the results with the traps located on towers outside the orchard, consistent differences in the number of mites trapped on panels oriented north, south, east, or west did not occur (Tables 3 \& 4). Some significant differences were found on certain sample dates, however, which suggests that the prevailing winds from the northwest sometimes do influence the movement of mites inside the orchard. However, it appears that wind turbulence within the orchard is more important than the prevailing wind direction, and both spider mite and predator movements within the orchard were relatively uniform. No consistent differences were found in numbers of mites trapped at the 2 heights within the orchard, so the data are pooled in Tables $3 \& 4$.
Diurnal patterns of dispersal. Neither spider mites ( $P$. ulmi and $T$. pacificus) nor $M$. occidentalis dispersed uniformly throughout the day, based on the sampling conducted during 18-19 July 1983 (Fig. 3). During 1983, most of the spider mites sampled were $P$. ulmi, with only a few $T$. pacificus collected. Most dispersal occurred during the 16-22 $\mathrm{h}$ interval. Temperatures declined from 30 to $22.5^{\circ} \mathrm{C}$, relative humidity increased from 30 to $46 \%$, and average wind speed increased (Fig. 3). A similar pattern was observed during the second sampling interval (July 25-27), but the absolute number of mites trapped were very low, so they are not graphed. Because so few were trapped during the second week, we have too few replicates to determine if the dispersal pattern observed is typical.

There were no gross, order of magnitude, differences in the numbers of $P$. ulmi and $M$. occidentalis

Table 4. Movement of spider mites and M. occidentalis within Livingston-III almond orchard.

\begin{tabular}{|c|c|c|c|c|c|c|c|c|}
\hline \multirow{2}{*}{$\begin{array}{l}\text { Date panels } \\
\text { placed on } \\
\text { towers } \\
1982\end{array}$} & \multicolumn{4}{|c|}{$\begin{array}{c}\text { Mean spider mites (S.D.) } \\
\text { facing }\end{array}$} & \multirow{2}{*}{$\begin{array}{l}\text { Mean } \mathrm{M} \\
\text { North }\end{array}$} & \multicolumn{3}{|c|}{$\frac{\text { occldentalis }}{\text { panel.facing }}$ (S.D.) trapr } \\
\hline & North & South & Bast & West ${ }^{1}$ & & South & East & West ${ }^{1}$ \\
\hline May 26 & $\begin{array}{c}0 \\
(0)\end{array}$ & $\begin{array}{c}0 \\
(0)\end{array}$ & $\begin{array}{c}0.2 \\
(0.5)\end{array}$ & $\begin{array}{c}0.1 \\
(0.3)\end{array}$ & $\begin{array}{c}0 \\
(0)\end{array}$ & $\begin{array}{c}0 \\
(0)\end{array}$ & $\begin{array}{c}0 \\
(0)\end{array}$ & $\begin{array}{c}0 \\
(0)\end{array}$ \\
\hline June 2 & $\begin{array}{c}2.7 \\
(3.4)\end{array}$ & $\begin{array}{c}1.5 \\
(2.3)\end{array}$ & $\begin{array}{c}1.7 \\
(2.2)\end{array}$ & $\begin{array}{c}2.0 \\
(2.6)\end{array}$ & $\begin{array}{c}0 \\
(0)\end{array}$ & $\begin{array}{c}0 \\
(0.1)\end{array}$ & $\begin{array}{c}0 \\
(0)\end{array}$ & $\begin{array}{c}0 \\
(0)\end{array}$ \\
\hline 16 & $\begin{array}{c}5.0 \\
(3.7)\end{array}$ & $\begin{array}{c}4.6 \\
(5.2)\end{array}$ & $\begin{array}{c}5.1 \\
(5.0)\end{array}$ & $\begin{array}{c}6.0 \\
(5.1)\end{array}$ & $\begin{array}{c}0 \\
(0.1)\end{array}$ & $\begin{array}{c}0 \\
(0.1)\end{array}$ & $\begin{array}{c}0 \\
(0)\end{array}$ & $\begin{array}{c}0 \\
(0)\end{array}$ \\
\hline 23 & $\begin{array}{c}5.8 \\
(4.9)\end{array}$ & $\begin{array}{c}5.2 \\
(5.7)\end{array}$ & $\begin{array}{c}5.8 \\
(5.5)\end{array}$ & $\begin{array}{c}7.7 \\
(6.5)\end{array}$ & $\begin{array}{c}0 \\
(0)\end{array}$ & $\begin{array}{c}0.2 \\
\cdot(0.4)\end{array}$ & $\begin{array}{c}0.2 \\
(0.6)\end{array}$ & $\begin{array}{c}0.2 \\
(0.4)\end{array}$ \\
\hline July 1 & $\begin{array}{c}32.5 \\
(26.0)\end{array}$ & $\begin{array}{c}28.1 \\
(21.9)\end{array}$ & $\begin{array}{c}26.8 \\
(15.9)\end{array}$ & $\begin{array}{c}29.3 \\
(20.4)\end{array}$ & $\begin{array}{c}1.0 \\
(1.5)\end{array}$ & $\begin{array}{c}0.3 \\
(0.5)\end{array}$ & $\begin{array}{c}0.5 \\
(0.9)\end{array}$ & $\begin{array}{l}1.0 \\
(1.5)\end{array}$ \\
\hline 7 & - & - & - & - & $\begin{array}{c}1.5 \\
(2.5)\end{array}$ & $\begin{array}{c}0.4 \\
(0.6)\end{array}$ & $\begin{array}{c}0.5 \\
(0.6)\end{array}$ & $\begin{array}{c}0.7 \\
(0.9)\end{array}$ \\
\hline 14 & $\begin{array}{c}15.3 \\
(16.5)\end{array}$ & $\begin{array}{c}15.7 \\
(16.1)\end{array}$ & $\begin{array}{c}20.3 \\
(23.4)\end{array}$ & $\begin{array}{c}23.4 \\
(24.2)\end{array}$ & $\begin{array}{c}2.5 \\
(2.9)\end{array}$ & $\begin{array}{c}3.1 \\
(3.4)\end{array}$ & $\begin{array}{c}2.0 \\
(2.4)\end{array}$ & $\begin{array}{c}3.4 \\
(2.6)\end{array}$ \\
\hline 21 & $\begin{array}{c}7.9 \\
(9.5)\end{array}$ & $\begin{array}{c}5.9 \\
(11.7)\end{array}$ & $\begin{array}{c}4.5 \\
(5.2)\end{array}$ & $\begin{array}{c}7.1 \\
(8.6)\end{array}$ & $\begin{array}{c}1.5 \\
(1.5)\end{array}$ & $\begin{array}{c}0.9 \\
(1.4)\end{array}$ & $\begin{array}{c}0.6 \\
(1.3)\end{array}$ & $\begin{array}{c}1.7 \\
(1.9)\end{array}$ \\
\hline 28 & $\begin{array}{c}7.5 \\
(8.4)\end{array}$ & $\begin{array}{c}4.9 \\
(7.3)\end{array}$ & $\begin{array}{c}5.2 \\
(6.6)\end{array}$ & $\begin{array}{c}7.4 \\
(8.5)\end{array}$ & $\begin{array}{c}3.7 \\
(3.4)\end{array}$ & $\begin{array}{c}4.0 \\
(5.7)\end{array}$ & $\begin{array}{c}3.1 \\
(3.8)\end{array}$ & $\begin{array}{c}2.7 \\
(2.5)\end{array}$ \\
\hline Aug. $11^{2}$ & $\begin{array}{c}0.4 \\
(0.6)\end{array}$ & $\begin{array}{r}8.5 b \\
(0.7)\end{array}$ & $\begin{array}{r}0.5 b \\
(1.2)\end{array}$ & $\begin{array}{l}1.3 a \\
(1.7)\end{array}$ & $\begin{array}{c}0.5 \\
(0.8)\end{array}$ & $\begin{array}{c}0.3 \\
(0.5)\end{array}$ & $\begin{array}{c}0.4 \\
(0.7)\end{array}$ & $\begin{array}{c}0.6 \\
(1.3)\end{array}$ \\
\hline
\end{tabular}

1 Mites were trapped on 16 panels $(175 \times 75 \mathrm{~mm})$ at each of 6 sites; at each 81 te, 4 panels

each faced north, south, east and west.

2 Means significantly different at the $5 \%$ level when tested with a one way ANOVA. 


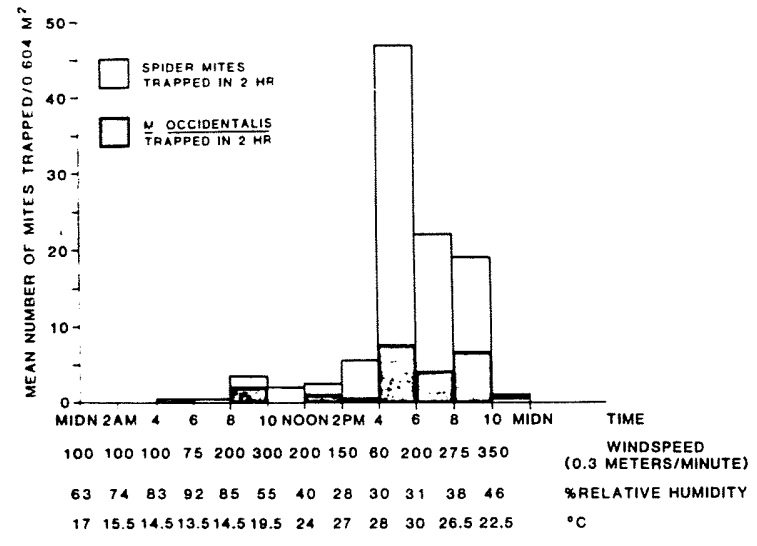

Fig. 3. Dispersal of spider mites and $M$. occidentalis every $2 \mathrm{~h}$ during July $18-19,1983$ outside the Livingston-l almond orchard.

trapped at $2.75,4.6,7.3$ or $10.8 \mathrm{~m}$ within the orchard (Table 5). This suggests that traps located at any height within the orchard are equally good estimates of relative dispersal densities. Thus there is no evidence that exceptionally large numbers of mites disperse out of the top of the almond tree. The two towers (east and west, Fig. 1) were expected to provide comparable data. However, the numbers of spider mites and predators trapped on the east tower was significantly greater than the number trapped on the west tower for both of the weeks sampled (Table 5).

Dispersal distance. Fluorescent dust was found on the greased panels $15,25,50,100$, and $200 \mathrm{~m}$ from the dusted trees. However, the dust particles were not associated with either spider mites or predators.
The reasons for this are unknown as preliminary laboratory trials showed that predators could be so marked. Substantial numbers of spider mites and $M$. occidentalis were found $200 \mathrm{~m}$ away from the dusted site (Table 6), although we cannot be sure these mites came from the Livingston-1 orchard. However, it is likely that the mites either came from the Livingston-I or II orchards, since these are the closest mite sources in the area (Fig. 1). Even if the mites came from the Livingston-II orchard, the nearest almond tree is at least $200 \mathrm{~m}$ away. Thus, these predators can move at least $200 \mathrm{~m}$ with prevailing winds of ca. $100-200 \mathrm{~m} /$ minute (Fig. 3). In fact, there is no apparent decline in the numbers of mites trapped on the most distant tower.

Survey for carbaryl resistance in surrounding almond orchards. Four of 15 colonies of M. occidentalis collected from almond orchards surrounding the Livingston release sites exhibited a measurable level of carbaryl resistance, suggesting that the released strain had successfully dispersed and established in these sites. Eleven colonies exhibited $0 \%$ survival when tested with $2.4 \mathrm{~g}$ carbaryl a.i./liter water. This is typical of native populations of $M$. occidentalis tested to date from California almond, apple, and pear orchards and vineyards (Roush, 1979; Roush \& Hoy, 1981; Hoy, 1982). The colonies that exhibited $6,6,14$, and $34 \%$ survival are south and east of the release orchards, as might be expected if aerial movements occur primarily with the prevailing winds from the northwest, and were collected ca. $800 \mathrm{~m}$ from the nearest release site. Resistant and suscéptible laboratory colonies had 80 and $0 \%$ survival rates.

Table 5. Comparison of numbers of mites trapped at four heights within the Livingston-I almond orchard, 1983.

\begin{tabular}{|c|c|c|c|c|c|c|c|c|}
\hline \multirow{3}{*}{$\begin{array}{l}\text { Date and } \\
\text { tower location }\end{array}$} & \multicolumn{8}{|c|}{ Total number of mites on panels ( $m$ above ground) } \\
\hline & \multicolumn{2}{|l|}{2.75} & \multicolumn{2}{|l|}{4.6} & \multicolumn{2}{|l|}{7.3} & \multicolumn{2}{|l|}{10.8} \\
\hline & SM & $\mathrm{MO}^{1}$ & SM & MO & SM & MO & SM & MO \\
\hline \multicolumn{9}{|l|}{ July $18-25$} \\
\hline East tower & 224 & 70 & 178 & 30 & 302 & 95 & 408 & 67 \\
\hline West tower & 132 & 28 & 222 & 38 & 283 & 72 & 188 & 42 \\
\hline \multicolumn{9}{|l|}{ July 25 -Aug. 1} \\
\hline East tower & 166 & 14 & 168 & 28 & 662 & 64 & 320 & 40 \\
\hline West tower & 10 & 0 & 11 & 3 & 5 & 2 & 15 & 3 \\
\hline
\end{tabular}

isM = total no. of spider mites $/$ panel $\left(0.604 \mathrm{~m}^{2}\right) ; \mathrm{MO}=$ total no. of $M$. occidentalis/panel. 
Table 6. Spider mites and M. occidentalis trapped on panels south and east of fluorescent-dusted trees in the Livingston-I almond orchard, 1983.

\begin{tabular}{|c|c|c|c|c|c|c|c|c|c|c|}
\hline \multirow{3}{*}{$\begin{array}{l}\text { Interval } \\
\text { sampled }\end{array}$} & \multicolumn{10}{|c|}{ Distance $(m)$ from dusted trees } \\
\hline & \multicolumn{2}{|l|}{15} & \multicolumn{2}{|l|}{25} & \multicolumn{2}{|l|}{50} & \multicolumn{2}{|l|}{100} & \multicolumn{2}{|l|}{200} \\
\hline & $\mathrm{SM}^{\prime}$ & MO & SM & MO & SM & MO & SM & MO & SM & MO \\
\hline July $18-25$ & 84 & 30 & 98 & 37 & 40 & 17 & 32 & 21 & 27 & 8 \\
\hline July 25 -Aug. 1 & 41 & 23 & 34 & 11 & 26 & 15 & 18 & 7 & 64 & 19 \\
\hline
\end{tabular}

isM $=$ total no. spider mites panel $\left(0.604 \mathrm{~m}^{2}\right) ; \mathrm{MO}=$ total no. of $M$. occidentalis $/$ panel.

Survial of M. occidentalis at high temperatures. Hungry, mated $M$. occidentalis females can survive for $6 \mathrm{~h}$ at $35^{\circ} \mathrm{C}$ at $30 \% \mathrm{R}$.H., and more than $45 \%$ survive for $24 \mathrm{~h}$ at $30^{\circ} \mathrm{C}$ and $30 \%$ R.H. (Table 7). This seems to be sufficiently long that aerial movements can result in successful colonization of nearby orchards and vineyards. These temperatures and relative humidity conditions are similar to those experienced during the July 1983 field experiments (Fig. 3).

\section{General discussion}

During 1981-83, large numbers of M. occidentalis and spider mites dispersed during July and early August, both within and out of the 2 almond orchards (Tables 1-4; Hoy, 1982). Aerial dispersal thus appears to provide a mechanism for betweentree, between-row, and longer range movements of both predator and prey in almonds. Stabler (1913) first observed aerial movements of spider mites in

Table 7. Survival of hungry, newly-mated females of $M$. occidentalis at high temperatures at 30 and $80 \%$ R.H.

\begin{tabular}{llcccc}
\hline $\begin{array}{l}\text { Test } \\
\text { duration } \\
\text { (hours) }\end{array}$ & $\begin{array}{l}\text { Temp. } \\
{ }^{\circ} \mathrm{C}\end{array}$ & $\begin{array}{l}\text { Mean } \tau_{c} \\
\text { survival at } \\
30 \% \text { R.H. }\end{array}$ & (S.D.) & \multicolumn{3}{c}{$\begin{array}{l}\text { Mean \% } \\
\text { survival at } \\
80 \% \text { R.H. }\end{array}$} & (S.D.) \\
\hline 12 & 30 & 70 & $(26)$ & 95 & $(10)$ \\
24 & 30 & 45 & $(20)$ & 90 & $(12)$ \\
36 & 30 & 16 & $(26)$ & 100 & $(0)$ \\
48 & 30 & 0 & - & 93 & $(12)$ \\
6 & 35 & 100 & $(0)$ & 100 & $(0)$ \\
6 & 40 & 0 & - & 90 & $(12)$ \\
\hline
\end{tabular}

Relative humidity controlled with saturated calcium chloride in a 3.75 I desiccator; 20 or 25 q tested under each condition; desiccators were unopened until the test was complete.
California almonds, and Fleschner et al. (1956), Boykin \& Campbell (1983), Brandenburg \& Kennedy (1982), and others have described large scale aerial movements of spider mites in other crops. Recognizing that such movements occur is important in pest management programs. Orchard "hot spots' can serve as the infestation foci for the entire orchard, making spot treatments of spider mites highly justified, particularly when predator densities are low. Large scale aerial movements of spider mites could also explain the rapid infestations seen in several almond orchards in the tops of trees during July and August when densities during the preceding 2 weeks were exceptionally low (M. Hoy, unpubl.). These rapid population increases are attributable in part to the very high reproductive rate exhibited by spider mites in hot, dry conditions but they are probably due, in some cases, to immigration of large numbers of spider mites into the orchard from neighboring orchards with outbreak populations.

Aerial movements of both spider mites and $M$. occidentalis are correlated with the densities of each on the foliage, but factors other than density may influence dispersal rate. Perhaps the tree's physiological status has an important role, as dispersal of spider mites occurred shortly after hull split in 2 almond orchards during 1982 and 1983. Whether unique temperature, relative humidity, or wind conditions occurred at this time is unknown. All of these factors are known to influence arthropod dispersal (Pedgley, 1982; Wellington, 1983).

$M$. occidentalis appears to have a dispersal strategy similar to that of spider mites. Spider mites are aerial planktors, having a low probability of reaching a new resource (Mitchell, 1970). To enhance colonization rate, both spider mites and $M$. occi- 
dentalis compensate by having $\widehat{\partial} \hat{\partial}$ smaller than, and less abundant than, $\$$ 우 and thereby invest less biomass in the sex that does not disperse. Both spider mite and $M$. occidentallis 우 mate very shortly after their emergence as adults, making the success of any subsequent colonization more likely. In the case of this parahaploid predator, immediate mating is particularly necessary as unmated 우 cannot produce progeny (Hoy, 1979), a contrast to the situation in which unmated arrhenotokous spider mites can produce sons. Mitchell (1970) suggested that prior to dispersal spider mite reproduction would be stimulated so that a rapid increase in 우 occurred within a short interval. Whether $M$. occidentalis alters its sex ratio or its reproductive rate prior to dispersal is unknown, but their reproductive rate in the presence of abundant prey is sufficiently high that rapid increases in the standing crop of $Q 9$ occur rapidly. It is likely that, because $M$. occidentalis is an obligate predator, the absolute numbers of predator dispersants are always substantially lower than the number of spider mite dispersants from any particular site. This hypothesis is supported by the relative numbers of predators and spider mites trapped on panels during 3 years of sampling (Tables 1-4; Hoy, 1982).

In San Joaquin Valley almond orchards, movement out of the orchard appears to be primarily via prevaling winds from the northwest. Within the almond orchard, dispersal of spider mites and predators appears to be less dependent upon prevailing winds and more uniform, presumably due to complex wind patterns within the orchard. These movements within the orchard explain how pesticide-resistant predators released into a few trees within the orchard can spread throughout the orchard within a few weeks (Hoy, 1982; Pedgley, 1982).

There is no evidence that the majority of either spider mites or M. occidentalis moves to the tops of trees prior to dispersing; the numbers of spider mites and predators trapped on panels at 4 heights within the orchard did not differ. Dispersal of both spider mites and $M$. occidentalis during one 24-h interval did occur when weather conditions were optimal for survival; i.e. temperature decreased, relative humidity increased, and wind speed was low to moderate. Whether spider mites and $M$. occidentalis commonly disperse during late afternoon through early evening is unknown, but these conditions are common in the San Joaquin Valley during the summer, and dispersal at this time would have great selective value.

Large numbers of spider mites and lesser numbers of $M$. occidentalis dispersed out of the Livingston-I and III orchards over the 1982 and 1983 seasons. Despite this, almond orchards in a 0.5 mile radius surrounding the sites where the carbaryl-OP resistant $M$. occidentalis were released had no, or only low to moderate levels of, carbaryl resistance. Even assuming that the predators survived the requisite number of mins/ $h$ in the hot, dry air to arrive at a suitable host plant, a number of other conditions must be suitable if establishment is to occur. A colonizing predator must find prey; it must not suffer application of inappropriate pesticides (the carbaryl-OP or carbaryl-OP-sulfur resistant strains are susceptible to pyrethroid insecticides), and it must compete successfully with any native phytoseiid predators in the orchard. Even though acaricides such as cyhexatin or propargite are selective, full application rates of these could result in such low levels of prey, at least for several weeks, that starvation could occur particularly since $\mathrm{M}$. occidentalis does not feed on pollen or nectar. Therefore, if an almond grower would like to establish the pesticide-resistant strains of $M$. occidentalis in his orchard, he should not rely on natural spread, as it appears to be too slow. Mass rearing and release is feasible, and is a more reliable method of establishment (Hoy et al., $1982 \mathrm{a}, \mathrm{b}$ ).

Conversely, movements of susceptible native $M$. occidentalis into these release sites appear to be sufficiently low that the pesticide-resistant strains should persist for at least several years. The ambiguity in the trap information (i.e., the correlation between high densities on panels facing both into and out of the south and east sides of the orchards) makes it difficult to estimate the number of predators coming into the orchard accurately, but the number must be very low in relation to the density already present. Other field data support this; the carbaryl-OP resistant strain was released into a Bakersfield orchard in 1979 and the carbaryl resistance level has not changed despite the fact that carbaryl was applied only once (in 1980) after the predators were released and the orchard is surrounded on 3 sides by almond orchards where the carbaryl-OP resistant strain was never released (Hoy, 1982; Hoy et al., 1984). Carbaryl was not 
applied during 1983 in the Livingston-I or III almond orchards, yet the resistance levels of the predators remain high to moderate. Thus, available evidence supports the hypothesis that dilution of the resistant strains, once established in the orchard, will not occur in significant amounts over a 1-4 year interval, which is the longest period these resistant strains have been evaluated. Persistence of the resistant strains, barring application of inappropriate pesticides, is sufficiently good that releases should be considered to provide permanent establishments.

\section{Acknowledgments}

We thank D. Cahn, D. Castro, F. Cave, W. Barnett and L. Hendricks for assistance, E. A. Bernays for comments and C. V. Horton for use of the almond orchards. The work was supported by funds from California Experiment Station Project 3522-H; Almond Board of California; Statewide IPM Project, University of California; and Western Regional Research Project W-84.

\section{Résumé}

Influence de la dispersion aérienne sur la persistance et la diffusion de Metaseiulus occidentalis résistants aux insecticides dans les vergers d'amandiers en Californie

La dispersion aérienne du phytoseïdae, $M$. occidentalis (Nesbitt), a été estimée comme élément de la lutte contre les populations résistantes aux insecticides établies dans les vergers de Californie. La dispersion maximale s'est produite fin juillet et début août en 1982 et 1983. La plupart des prédateurs (et des acariens) quittent les vergers avec les vents dominants du nordouest. Dans le verger, les vents dominants sont moins importants et la dispersion est généralement au hasard. Tant les acariens que les prédateurs se dispersaient au hasard par rapport à la taille des amandiers, mais les relevés sur 24 heures laissent supposer qu'il n'y a pas une distribution aléatoire pendant la journée. La plupart des mouvements aériens se produisirent entre 16 et 22 heures quand $\mathrm{HR}$ et vitesse du vent augmentaient et température diminuait. Les acariens et prédateurs ont été piégés sur des panneaux à $200 \mathrm{~m}$ du verger.
Le contrôle des niveaux de résistance au carbaryl de $M$. occidentalis, récoltés dans les vergers d'amandiers entourant le point de lâcher, montre que les individus résistants se sont dispersés à au moins 800 $m$ de 1981 à 1983. Cependant, les arboriculteurs souhaitant utiliser des souches résistantes devront les lâcher dans les vergers, car la dispersion naturelle est trop lente. La migration de $M$. occidentalis indigènes dans les lieux de lâcher est apparue suffisamment rare pour que la dilution des souches résistantes au carbaryl soit minime pendant 2 à 4 ans.

\section{References}

Bernstein, C., 1983. Some aspects of Phytoseiulus persimilis (Acarina: Phytoseiidae) dispersal behavior. Entomophaga 28: $185-198$.

Bernstein, C., 1984. Prey and predator emigration responses in the acarine system. Tetrany'chus urticae - Phytoseiulus persimilis. Oecologia 61: 134-142.

Boykin, L. S. \& W. V. Campbell, 1984. Wind dispersal of twospotted spider mite (Acari:Tetranychidae) in North Carolina peanut fields. Environ. Entomol. 13: 221-227.

Brandenburg, R. L. \& G. G. Kennedy, 1982. Intercrop relationships and spider mite dispersal in a corn/ peanut agro-ecosystem. Ent. exp. \& appl. 32: 269-276.

Field, R. T., 1981. Evaluation of genetically-improved strains of Metaseiulus occidentalis (Nesbitt) (Acarina:Phytoseiidae) for integrated control of spider mites on roses in greenhouses. Univ. Calif. Berkeley, Ph.D. Thesis, 116 pp.

Fleschner, C. A., M. E. Badgley, D. W. Ricker \& J. C. Hall, 1956. Air drift of spider mites. J. econ. Entomol. 49: 624-627.

Hoelscher, C. E., 1967. Wind dispersal of brown soft scale crawlers, Coccus hesperidum (Homoptera: Coccidae), and Texas citrus mites, Eutetranychus banksi (Acarina: Tetranychidae) from Texas citrus. Ann. entomol. Soc. Amer. 60: 673-678.

Hoy, M. A., 1979. Parahaploidy of the 'arrhenotokous' predator, Metaseiulus occidentalis (Acarina: Phytoseiidae), demonstrated by X-irradiation of males. Ent. exp. \& appl. 26: 97-104.

Hoy, M. A., 1982. Aerial dispersal and field efficacy of a genetically improved strain of the spider mite predator Metaseiulus occidentalis. Ent. exp. \& appl. 32: 205-212.

Hoy, M. A. (In press). Genetic improvement of a biological control agent: multiple pesticide resistances and nondiapause in Metaseiulus occidentalis (Nesbitt) (Phytoseiidae). Proc. VI Internat. Congr. Acarology, Edinburgh, August, 1982.

Hoy, M. A. \& N. F. Knop, 1979. Studies on pesticide resistance in the phytoseiid Metaseiulus occidentalis in California. Rec. Adv. Acarol. I: 89-94.

Hoy, M. A., W. W. Barnett, W. O. Reil, D. Castro, D. Cahn, L. C. Hendricks, R. Coviello \& W. J. Bentley, 1982a. Largescale releases of pesticide-resistant spider mite predators. Calif. Agric. 36(1/2): 8-10. 
Hoy, M. A., D. Castro \& D. Cahn. 1982b. Two methods for large scale production of pesticide-resistant strains of the spider mite predator Metaseiulus occidentalis (Nesbitt) (Acarina: Phytoseiidae). Zeitsch. angew. Entomol. 94: 1-9.

Hoy, M. A., W. W. Barnett, L. C. Hendricks. D. Castro, D. Cahn \& W. J. Bentley, 1984. Managing spider mites in almonds with pesticide-resistant predators. Calif. Agric. 38(7/8): 18-20.

Johnson D. T. \& B. A. Croft. 1976. Laboratory study of the dispersal behavior of Amblyseius fallacis (Acarina: Phytoseiidae). Ann. Entomol. Soc. Amer. 69: 1019-1023.

Johnson, D. T. \& B. A. Croft. 1981. Dispersal of Ambliseius fallacis (Acarina: Phytoseiidae) in an apple ecosystem. Environ. Entomol. 10: 313-319.

Mitchell, R., 1970. An analysis of dispersal in mites. Amer. Natur. 104: 425-431.

Pedgley, D. E., 1982. Windborne pests and diseases, meteorology of airborne organisms. Ellis Horwood Ltd.. Chichester, $250 \mathrm{pp}$.
Roush, R. T., 1979. Selection for insecticide resistance in Metaseiulus occidentalis (Nesbitt)(Acarina: Phytoseiidae): genetic improvement of a spider mite predator. Ph.D. thesis, Univ. of Calif., Berkeley, $87 \mathrm{pp}$.

Roush, R. T.\& M. A. Hoy, 1981. Laboratory, glasshouse and field studies of artificially selected carbaryl resistance in $\mathrm{Me}$ taseiulus occidentalis. J. econ. Entomol. 74: 142-147.

Stabler, H. P., 1913. Red spider spread by winds. Monthly Bull. Calif. State Comm. Hort. 2: 777-780.

Washburn, J. O.\& L. Washburn, 1983. Active aerial dispersal of minute wingless arthropods: exploitation of boundary-layer velocity gradients. Science 223: 1088-1089.

Wellington, W. G., 1983. Biometeorology of dispersal. Bull. Entomol. Soc. Amer. 29: 24-29.

Winston, P. W. \& D. H. Bates, 1960. Saturated solutions for the control of humidity in biological research. Ecol. 41: 232-237.

Accepted: July 5, 1984 